\title{
The Deaf Students' in Writing English Text by Using Recount Text
}

\author{
Sri NintaTarigan \\ Universitas Prima Indonesia \\ srinintatarigan@gmail.com
}

\begin{abstract}
The problem of this study is how Recount Text application in writing English text was and what the obstacle was. The purpose of this research is to find how Recount Text application in writing in English was and to find out what the obstacles was. The method used in this research was qualitative method in the form of case studies. The population was students of SLB Taman Pendidikan Islam. The number of students consists of 7 students and the whole will be sampled in the study. The conclusion of this research was found that recount text need more practice. It means that the application of recount text was not implicate well in Extraordinary School (SLB) Taman Perguruan Islam Medan. Teacher should be given many vocabularies. Vocabularies were the important things in writing text. How students able write well if they did not have vocabulary references. The solution of this problem was deaf students should be given short story so they can not only enjoy the story but also have many vocabulary references. The location of this research was in the Disable School (SLB) ABC Taman Pendidikan Islam (TPI) which was located at Jl. Sm. Raja Km. 7 no.5 Harjosari Medan. The conclusion of this research was found that recount text need more practice. It means that the application of recount text was not implicate well in Extraordinary School (SLB) Taman Perguruan Islam Medan.
\end{abstract}

Keywords: writing achievement, recount text, kids with special needs

\section{Introduction}

Recount text is a text that writes about the experience, write about something that they thought it can give entertain to the reader. Gerot and Winkle (1994) said that the purpose of this text is to give the information and entertain the reader. Their experience was written in recount text. The sentences did not come suddenly. It had a process. It would come if a writer read many references. From all the references that have read so the writer will be easier to arrange many sentences.

To deaf students, writing was good tool to communicate. The deaf students would decant all of their idea, opinion, and expression of their experience. Reading was the way for them to study English and to decant their idea; it will be easy with writing text. All the students could know their idea especially for common students. Heilman (1981) said that reading is a process to find the writer's idea through the meaning interpretation and reading make the process of thinking and communication will run well. It means that reading can make good in communication.

As generally, education is for everyone; deaf students also have the same rights to normal students. The education is given to the deaf students in extraordinary school (SLB) in Taman Perguruan Islam Medan. It said in UUD 1945 in Article 28C Paragraph 1 which told that "Everyone has the right to develop themselves through the fulfillment of basic needs, the right to receive education and gain the benefits of science and technology, arts and culture, in order to improve the quality of life and for the welfare of mankind." 
Article 31 Paragraph 2 in Constitution (UUD) 1945 bold that the government has an obligation to seek the implementation of national teaching in the context of life, by prioritizing budget of at least 20 per cent of the Budget (APBN) and Budget (APBD), but the weakness of the content of Article 31 paragraph (2) Constitution 1945 (after the change) has no sanctions to the government if Article 31 paragraph (2) 1945 (after the change) is not implemented. They also need education for survival and for their future. They also have a dream and the desire to know the world around.

Their limitations sometimes are not so visible to the normal students, but today many students with their limitations would be able to amaze the world. There have been many stories of students with disabilities were able to reach up and the story is exactly what motivates them to want to live like a normal student. Currently, it is time for every teacher must be teachers in special schools, to serve the students who really need special treatment. College curriculum should also be able to see what is needed by the people so that when they have completed their college as prospective teachers so they do not just teach in a regular school, but also capable of serving in a special school for children with special for disabilities .

Deaf children Indonesia almost $90 \%$ of them pass without a language. Deaf children have been marginalized within his rights as a result of a proper education of uncommon method of education for them. So practically deaf children in Indonesia are backward in education. In fact, by applying the system of 'bilingualism' in the language of instruction of the school by providing sign language as their mother tongue, will allow deaf children to have social maturity, cognitive and linguistic better, (Sukmara, 2008)

Teachers are expected to understand the difficulties deaf students and understand what their barriers in the learning process so that they can accomplishment, (Swanwick\&Marschark, 2010).

Motivating students with hearing impairment is one of the solutions so that their enthusiasm in learning. Without them knowing they are sometimes ostracized by society because of their hearing ability is not functioning optimally and considers that most students cannot learn like deaf people who do not require special attention. According to (Sally; 2010) is a method that can motivate conjured learning to student success.

The background of the writer entitled "Implementation Recount Text to Improve Writing Ability in Learning English for Extraordinary School (SLB) Taman Perguruan Islam (TPI) Medan" is to provide solutions to teachers who teach in schools with special needs and the researchers also wanted to knowing how effective the implementation of Recount Text in students' ability to write their personal experiences. The problem of this study is how Recount Text application in writing in English was and what the obstacle was. The purpose of this research is to find how Recount Text application in writing in English was and to find out what the obstacles was.

\section{Deaf Students}

Deaf Students can be defined as a state of hearing loss that results in a person cannot catch a variety of stimuli, especially through the senses of hearing. In addition, (Mufti Salim; 1984) concluded that:"Children with hearing impairment are children who experience lack or loss of hearing ability due to damage or malfunction in part or their entire hearing instrument so that it faces obstacles in language development. He needed guidance and special educations to achieve inner and outer life are worth it. "(Mufti Salim, in SutjihatiSomantri, 2006: 93).

Deaf Students can be divided into two categories, they are:

1. Deaf

Deaf is senses of hearing damage in its early stages so that the weight loss does not work anymore.

2. Low of Hearing

Published by English Lecturers and Teachers Association (ELTA)

Copyright (C) 2021, authors , 
Low of hearing is sense of hearing is damaged but can still function to hear, either with or without the use of hearing aids (hearing aids).

A deaf child is a child who experienced a lack or loss of hearing ability due to damage or malfunction in part or all of the hearing instrument so that he faces obstacles in language development, (Meliayawati; 2012).

Speech and language development is closely related to hearing acuity. Due to lack of sharpness of hearing, deaf children are not able to hear properly. Thus, in children with hearing impairment does not occur after the process of imitation voice babble, copy process is confined to the visual imitation. Furthermore, the development of speech and language, hearing impaired children require special and intensive coaching according to ability and level of deaf students. Expressive language disorder is a disorder that inhibits a child's ability to communicate symbolically both visually (writing, marking) or auditory. In an expressive language disorder, clinically can find symptoms such as vocabulary is clearly limited, made a mistake in the vocabulary, have difficulty in remembering words or to form long sentences and has difficulty in academic achievement, and social communication, but understanding the language of children remained relatively

intact.

The development of the ability to speak a series of measures so that children have the knowledge, skills, and attitudes to express thoughts, ideas, and feelings have a manner of speaking. Nugroho (2004) quoted Herawati pointed out that the service of talk has three purposes, namely:

1. In the field of knowledge, so that children have knowledge about: the event say the whole sound Indonesian; b) how to say the word, group of words and sentences Indonesian; c) evaluating own speech, based on visual observations, auditory, and kinesthetic; d) controlling tool for improving the quality of speech he said; and e) the choice of words and groups of words.

2. Field of skills, so that children of skilled: a) pronounce the sounds of Indonesian; b) pronounce the word, group of words, and sentences Indonesian; c) evaluating own speech based on visual observations, auditory, and kinesthetic; d) controlling the tool he said for the sake of quality improvement of speech; and e) use of words, groups of words and sentences in accordance with the ideas and good grammar and correct.

3. In the area of attitude, so that the child has: her) happy to use speech in communicating with others; b) glad to conduct an evaluation and fix the mistakes and try to improve his abilities. The final goal building for deaf children to speak is that he has the knowledge, skills, and attitudes basis for: a) communicate in society; b) work and integrate in public life; and c) develop in accordance with the principle of lifelong education.

\section{Recount Text}

Recount Text is the text that contains the experiences of a writer by the events that are giving the impression that is hard to forget. The purpose of this text is Recount activities focused on providing information to the reader. According to (Gerot and Winkle, 1994) recount text is communicating and the purpose is to inform the experience of the writer. In the text recount there are some things that will be focused by the student is generic structure. Consisting of:

1. Orientation tells who was involved, what happened, where the events took place, and when it happened.

2. $\quad$ Events tell what happened and in what sequence.

3. Reorientationconsists of optional-closure of events/ending. 


\section{Writing Score}

Hughey in Teaching ESL Writing (Reid, 1993) said that there five components in writing score. They are:

1. Content: The ability to think creatively and devolve thoughts including all of the relevant to assigned topic.

2. Organization: The ability to write in appropriate for a particular audience in mind, together with and ability to select, organize and other relevant information.

3. Vocabulary: The ability to write the world effectively and to appropriate register.

4. Language Use: The ability to use correctly those conventions peculiar to written language-e.g. punctuation and spelling.

5. Mechanisms: The student's ability in using word appropriately using function word in a paragraph and the text correctly.

\section{Research Method}

The method used in this research was qualitative method in the form of case studies. Qualitative research was important approach for understanding a social phenomenon and the perspective of individuals studied. The aim is to describe study and explain the phenomenon. The techniques which are used in this research was tests, observations and interviews. Observations and interviews was conducted by the author, namely the observation of the behavior of any object that was done and the response shown at the time of observation in progress and some of the questions that support for research. The population was students of SLB Taman Pendidikan Islam. There are 7 studentstsources aken as the data

The location of this research was in the School (SLB) ABC Taman Pendidikan Islam (TPI) which was located at Jl. Sm. Raja Km. 7 no.5 Medan, Harjosari Medan. The reason this research was determining the location of the first, similar research had never been held before. Second, is to provide experience to students SLB in Taman Pendidikan Islam. The study will last for 5 (five) months from March to July 2014.

This study will take place in one semester (10 weeks) with two meetings a week. Each meeting lasted 35 minutes. Students would be given a briefing on the matter. Researchers would work closely with the teacher or homeroom in Schools Islamic Education Taman Medan. Researchers would carry out teaching himself assisted by a teacher or homeroom would be observed the teaching and learning process.

\section{Research Finding}

The research was finding that the ability of deaf students writing recount text was good. This criterion was good step to write in English. The difficult way was found in this research. For examples are the communication between students and researcher, the way to teach those English, and the lowest vocabulary mastery. For make it clear, the reader can read table below.

Table. 1 Writing Ability

\begin{tabular}{|c|c|c|c|c|c|c|}
\hline No. & $\begin{array}{c}\text { Student } \\
\text { Initial Names }\end{array}$ & Content & Organization & Vocabulary & $\begin{array}{l}\text { Language } \\
\text { Use }\end{array}$ & Mechanism \\
\hline 1. & JAN & 勾 & 勾 & - & $\sqrt{3}$ & - \\
\hline 2. & MHD & 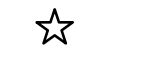 & - & - & - & - \\
\hline 3. & SEL & 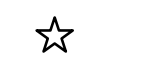 & $i s$ & - & 岤 & 勾 \\
\hline
\end{tabular}

Published by English Lecturers and Teachers Association (ELTA)

Copyright (C) 2021, authors, 


\begin{tabular}{|c|c|c|c|c|c|c|}
\hline 4. & CIN & 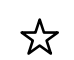 & - & - & - & - \\
\hline 5. & RYN & 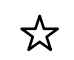 & 访 & - & - & - \\
\hline 6. & SEN & 23 & 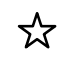 & - & - & - \\
\hline 7. & BEN & 它 & - & - & - & 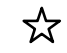 \\
\hline
\end{tabular}

From the table above it was shown that students' vocabulary mastery was low. The second was language use and mechanism. The content in the students' writing was good but they could not arrange well in English. Some of them still use bahasa Indonesia in their recount text.

\section{Conclusion}

The conclusion of this research was found that recount text need more practice. It means that the application of recount text was not implicate well in Extraordinary School (SLB) Taman Perguruan Islam Medan. Teacher should be given many vocabularies. Vocabularies were the important things in writing text. How students able write well if they did not have vocabulary references. The solution of this problem was deaf students should be given short story so they can not only enjoy the story but also have many vocabulary references.

The obstacle of this research was the communication to the students. It was very hard to deliver the researcher idea because they cannot hear the researcher. They only read our lips to understand what the researcher says. Here the researcher was not work alone, he worked together with homeroom teacher. The big important to solve the problem is love and care. If a teacher has a love in teaching of course she/he will have mercy in teaching. She/he will care about everything in students need at class.

\section{References}

Detterman, D.K. \& Thompson, L.A. 1997. What is so special about special education? American Psychologist, 52: 1082-1090.

Gerot and Wignell. (1994). Making Sense of Functional Grammar.

Sidney: University of South Australia.

Harmer, J. (2004).How to Teach Writing. England: Pearson Education.

Heilman, Blair and Ruplei.(1981). Principles and Practices of Teaching Reading. London: Merril.

Hernawati, Tati. (2007, 1 Juni).PengembanganKemampuanBerbahasadanBerbicaraAnakTunarungu). Bandung (tidakditerbitkan)

Sukmara, Galuh. 2008. Yayasan Akrab.com.

Sutjihati Somantri, 2006, PsikologiAnakLuarBiasa. Jakarta. Depdikbud.

Swanwick, Ruth \&Marschark, Mark, 2010.Enhancing Education for Deaf Children: Research into Practice and Back Again, Deafness \& Education International Journal, Vol. 12 No. 4, December, 2010, 217 235.University of Leeds \& University of Edinburg. United Kingdom.

Published by English Lecturers and Teachers Association (ELTA)

Copyright (C) 2021, authors , 